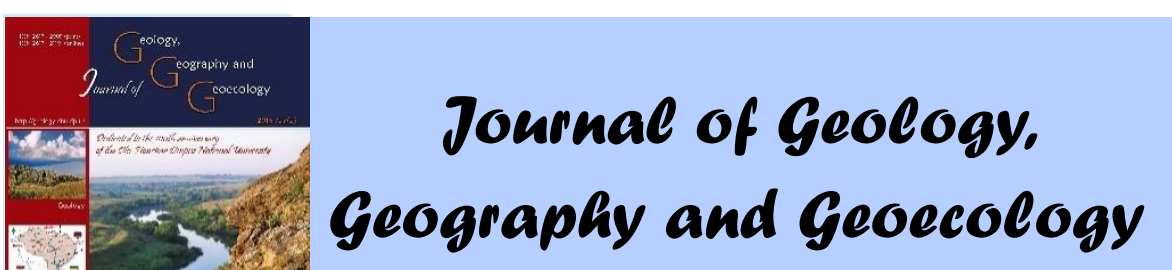

Journal home page: geology-dnu-dp.ua

\title{
Demographic transformation in the agglomerations of Dnipropetrovsk region
}

\author{
V.V. Bezugly, Z.V. Boyko, O.V. Tsvietaieva \\ Oles Gonchar Dnipro National University, Dnipro, Ukraine, e-mail: vetalbezugly@ukr.net
}

Received 12.12.2018;

Received in revised form 14.01.2019;

Accepted 19.02.2019
Abstract. This article examines the demographic situation in Dnipropetrovsk region and identifies the main demographic problems of the region, among which the most important are low fertility, reduced family size, high divorce rates and unregistered marriages, contimuing aging of the population, increased gender disproportion among the population, intra-regional and especially modern external migrations of the population, etc. The Dnipropetrovsk settlement system includes four industrial agglomerations: Dniprovsky-Kamianske, Kryvyi Rih, Nikopol and Pavlohrad, where more than $83.5 \%$ of the region's population lives , indicating a high level of urbanization of the territory. It was found that the dynamics of the population of the urban agglomerations of the Dnipropetrovsk region over the past 20 years has a tendency to progressive reduction: if in 1997 the size of the existing population amounted to 3,888.8 thousand people, in 2017 it amounted to $3,227.5$ thousand people. It is stated that the natural replenishment of the population provides a continuous change of generations, creating the quantitative boundaries of labour resources of urban agglomerations of Dnipropetrovsk region. The current state of migration processes in the agglomerations of Dnipropetrovsk region is caused by socio-economic and political problems. This has led to an increase in labour out-migration, which now has already become catastrophic, not only in the Dnipropetrovsk region, but throughout Ukraine. Negative consequences of this are the depopulation of cities and areas of agglomerations, the outflow of high quality labour potential (and in particular qualified labour), the collapse of families, rise in crime and corruption, etc. In general, it is established that the demographic aspect, due to natural and mechanical movements, has become a determining factor in the formation of the labour resource situation and affects not only the process of replenishmnent itself, but also the structure of the economically active population. We present the general demographic features of the population's reproduction, in the urban agglomerations of Dnipropetrovsk region from 1997 to 2017; a decrease in the total population, a negative natural population growth (mortality rates will prevail over birth rates), aging of the population, which is reflected in an increase in the number of people aged 70 , disproportion in the sexual structure of the population (prevalence of women), negative balance of migration and continuous outflow of inhabitants of reproductive age, especially to the countries of the European Union.

Keywords: demographic state, Dnipropetrovsk region, urban agglomerations, depopulation, natural increase, migration, labour migration

\section{Демографічна трансформація в агломераціях Дніпропетровської області}

\author{
В.В. Безуглий, 3.В. Бойко, О.В. Цвєтаєва
}

Дніпровський національний університет імені Олеся Гончара, Дніпро, Украӥна, е-таil: vetalbezugly@ukr.net

Анотація. Розглянуто демографічний стан населення Дніпропетровщини, визначені основні демографічні проблеми області. Дніпропетровська система розселення включає чотири промислові агломерації: Дніпровсько-Кам'янську, Криворізьку, Нікопольську і Павлоградську, в яких проживає більше 83,5 \% населення області, що свідчить про високий рівень урбанізованості території. Виявлено, що динаміка населення міських агломерацій Дніпропетровського регіону за останні 20 років має тенденцію до поступого скорочення: якщо в 1997 р. чисельність наявного населення становила 3888,8 тис. осіб, то в 2017 р. - вже 3227,5 тис. осіб. 3`ясовано, що природне відтворення населення забезпечує безперервну зміну поколінь, створюючи кількісні межі трудових ресурсів міських агломерацій Дніпропетровського регіону. Сучасний стан міграційних процесів в агломераціях Дніпропетровської області зумовлений проблемами соціально-економічного та політичного характеру. Саме це призвело до підсилення трудової міграції, що нині набуло вже катастрофічних масштабів не лише в Дніпропетровській області, а в усієї Україні. Негативними наслідками цього виступають депопуляція міст і районів агломерацій, відтік кращого трудового потенціалу (і зокрема кваліфікованого), розпад сімей, злочинність і корупція тощо. В цілому встановлено, що саме демографічний аспект за рахунок природного і механічного рухів, став визначальним у формуванні працересурсної ситуації та впливає не тільки на сам процес відтворення, а й на структуру економічно активного населення. Із 1997 по 2017 роки в міських агломераціях Дніпропетровського регіону виявленні загальні демографічні особливості відтворювання населення: зменшення загальної чисельності населення, від’ємний природний приріст населення 
(показники смертності переважать над показниками народжуваності), постаріння населення, яке виражається в збільшенні чисельності осіб віком 70 років, диспропорція в статевій структурі населення (переважання жінок), від’ємне сальдо міграції і постіний відтік мешканців репродуктивного віку, особливо до країн Євросоюзу.

Ключові слова: демографічний стан, Дніпропетровська область, міські агломераиії, депопуляція, природний приріст, миграиії, трудова міграчія.

Relevance of the research. Research on the development of urban agglomerations and metropolises occurs mainly in economic, geographic, socio-economic, and political spheres. At the beginning of the XXI century, mankind faces many vital and difficult problems, among which the most important is the demographic problem. Depopulation is today the dominant demographic of many European countries. This problem is especially acute for Ukraine, where the natural population growth has become negative by reduction in birth rates and a sharp increase in mortality, reduced life expectancy, decreasing marriage rates and, on the contrary, increasing divorce rate, there is a massive migration flow from rural areas to the largest agglomerations, including those in Dnipropetrovsk region.

Modern geodemographic research is carried out by leading specialists of the Institute of Demography and Social Studies named after M.V. Ptuha of the National Academy of Sciences of Ukraine, as well as a whole pleiad of geographers (V. Dzhaman, F. Zastavny, S. Ishchuk, L. Nemets, G. Starostenko, A. Topciyev, M. Faschevsky, O. Homra, V. Yavorskaya, etc.). In most cases, the objects of their research are large territories (Ukraine and its administrative units - the regions), while these complex demographic processes have been severely neglected for industrial agglomerations. The current period of enlargement of large cities, the formation of a number of smaller settlements beyond their existing boundaries, their economic development and geographic expansion, makes the issue of considering these territories as urban agglomerations extremely necessary.

The purpose of the work is to provide a demographic characteristic of industrial agglomerations of one of the leading regions of Ukraine - Dnipropetrovsk region.

Presentation of the main research material. Industrialization, development of minerals, the creation of large scientific centers, and difficult living conditions in the countryside caused intensive urbanization processes, that is, the development of cities and the increase in the urban population in Dnipropetrovsk region.

The Dnipropetrovsk region settlement system includes four industrial agglomerations: DniproKamyanske, Kryvyi Rih, Nikopol and Pavlohrad. The high concentration of industry has created conditions for the development of the Dnipro-
Kamyanske agglomeration as a multiprofile, multifunctional center in Dnipropetrovsk region. It is polycentric, formed around several centers and has a total population of more than 1.4 million people, of which $92 \%$ live in towns and urban settlements (urban areas). The center of the Kryvy Rih agglomeration is the large city of Kryviy Rih. It stretches along the Saksagan and Ingulets rivers, $120 \mathrm{~km}$ from north to south, is the center of a developed industrial and agricultural specialization, in which there are about 850 thousand people (State Statistics Committee of Ukraine, 2018), including almost $90 \%$ of the local population concentrated in urban areas. Nikopol Agglomeration with its centre in the city of Nikopol reaches $70 \mathrm{~km}$ along the Dnieper River on the coast of the Kakhovsky Sea. It was formed on the basis of one of the world's largest manganese ore extraction basins (Nikopol manganese ore basin). Within this agglomeration, there are about 250 thousand people (Main Department of Statistics in Dnipropetrovsk region, 2018), of which more than $80 \%$ live in the urban area. Pavlohrad agglomeration with its centre in Pavlohrad stretches along the Samara and Vovcha rivers. It is monocentric, and its population is estimated at 299.94 thousand people.

The modern period of enlargement of large cities, the formation of a number of smaller settlements, their economic development and geographic expansion beyond their existing boundaries around them, makes the question of considering these territories as urban agglomerations extremely necessary.

In urban agglomerations more than $83.5 \%$ of the region's population lives, this indicates a high level of urbanization of the territory. The average population density is 104.5 persons $/ \mathrm{km}^{2}$.Excluding the large towns which they border, the districts of the region with the largest population density are Dnipropetrovs'k (59.1 persons $\left./ \mathrm{km}^{2}\right)$, Verkhnodniprovsk (42.2 persons $/ \mathrm{km}^{2}$ ), Apostolovo (41.8 persons $\left./ \mathrm{km}^{2}\right)$, Novomoskovsk (37.5 persons $\left./ \mathrm{km}^{2}\right)$, Kryvyi Rih (33.1 persons $\left./ \mathrm{km}^{2}\right)$, Tsarychanka (30.9 persons $\left./ \mathrm{km}^{2}\right)$ and Pokrov (30.4 persons $/ \mathrm{km}^{2}$ ) districts. The smallest population density is observed in Yur'evka district (15.5 persons $\left./ \mathrm{km}^{2}\right)$, in Sofievka $\left(17.2\right.$ persons $\left./ \mathrm{km}^{2}\right)$ and in Pavlohrad (19.9 inhabitants $/ \mathrm{km}^{2}$ ) district (Fig. 1).

The dynamic of the population of urban agglomerations of Dnipropetrovsk region during the last 20 years indicates its gradual reduction. So, 
if in 1997 the size of the existing population was 3888.8 thousand people, then in 2017 it was only 3227.5 thousand people. That is, the population declined by $17 \%$ (or decreased by 661.3 thousand people).

In the territorial aspect, the largest number of population is observed in Dnipropetrovsk (57 674 people), Novomoskovsk (57 674 people) and Apostolovo (57 674 people) districts, the smallest in Yuryevka (13 967 people). During 2017, the existing population of the region decreased by 19 thousand people, the main factor in the reduction in the number of inhabitants of the region was the natural decrease in the population, as a result of excess of deaths over births.

The lowest birth rates in the metropolitan areas of the Dnipropetrovsk region occurred in 1999-2001, when the number of births of children ranged from 26.1 to 25.7 thousand. In 2017, 36134 children were born in the region. The volume of natural reduction has increased by $7.3 \%$.

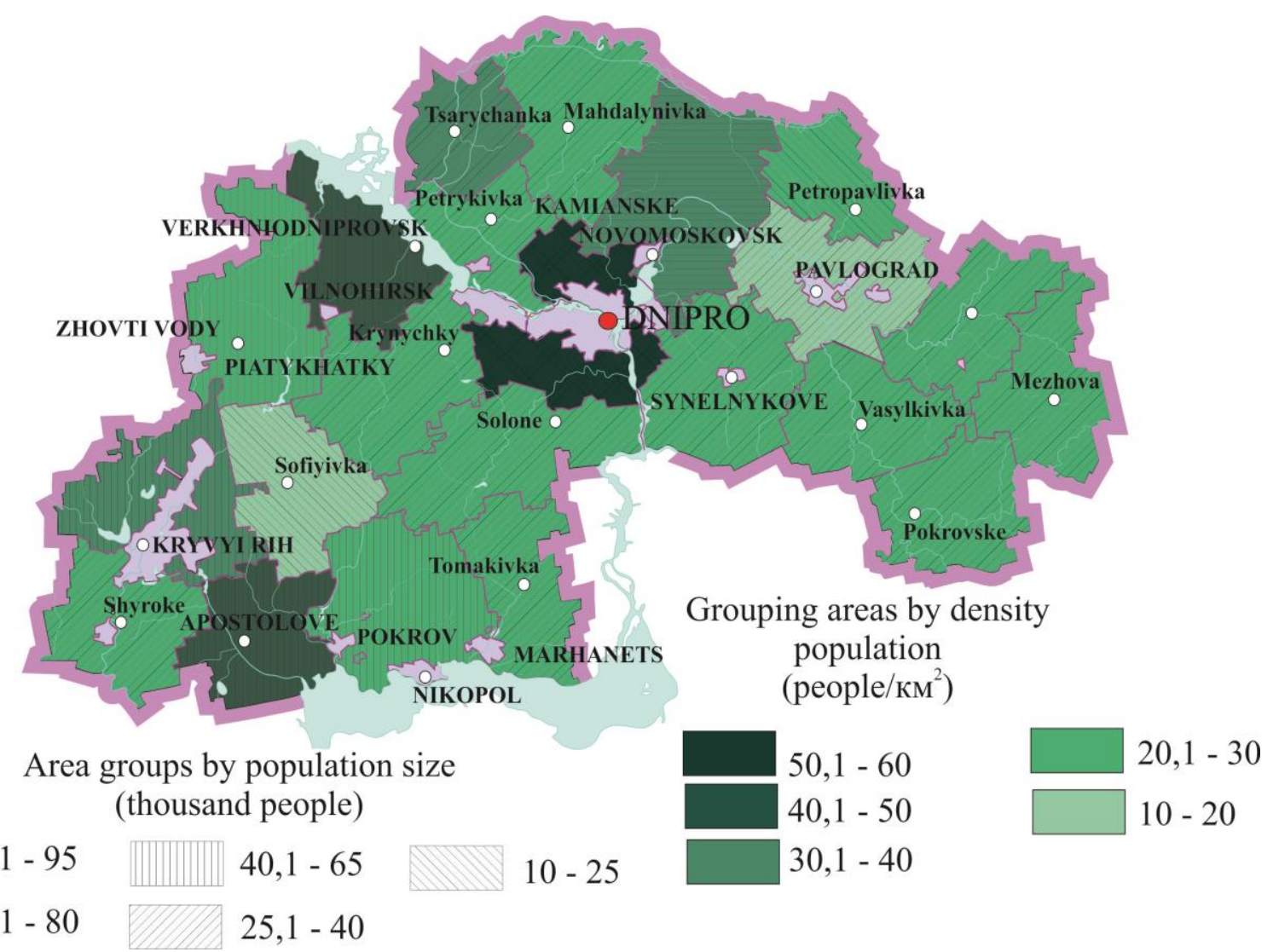

Fig. 1. Population and density of the population of Dnipropetrovsk region, 2017 Source: data retrieved from the official website Main Department of Statistics in Dnipropetrovsk Region

The highest fertility rate in 2017 was noted in Yuryevka (12.9 \%o), Krynychky (12.8 \%o), Novomoskovsk (12.7\%o), Sinelnikove and Shiroke (12.6\%) districts, the smallest - in Pavlohrad and Pokrovsk (9.6\%) districts (Main Department of Statistics in Dnipropetrovsk Region, 2018).

The dynamics of the number of births is affected by both the intensity of childbirth and structural changes in the sex-age population. Thus, according to a statistical analysis, the proportion of women aged 25-29 in the total population was $7.5 \%$ in 2017, against $6.7 \%$ in 2001 . It should be noted that women of the above age group account for almost one third of the total births.

Recently, changes in the ratio of children in the order of their birth are observed: the proportion of first-born children decreases and the number of second-borns increases. So, if in 2001 the share of the first -born children in the total number of births was $64.3 \%$, then in 2017 it was only $52.7 \%$, second-borns - respectively $27.9 \%$ and $35.5 \%$. This situation is connected, first of all, with the change of legislation in the state, with the enactment of the relevant legislative acts promoting the birthrate, etc.

The number of the labour force also depends on mortality rates of the population, especially the working age population. Analyzing the mortality rates of the population of the Dnipropetrovsk region, it should be noted that the largest number of deaths in the last twenty years was observed in 1997 (61.3 thousand people) and 2017 (61.2 thousand people). In other recent years, the number of deaths had decreased to 54.9 thousand people and 54.5 thousand people, respectively, which to some extent relates to the improvement of the socio-economic situation in the region, changes in 
the state demographic policy. The lowest mortality rate is observed in Dnipropetrovsk (14.2\%) and Novomoskovsk $(16.9 \%$ ) districts. The leaders in terms of the mortality rate are Sofievka $(22.5 \%)$, Shyroke (20.9 \%), Tsarychanka (20.5 \%), Petyikivka (20.4\%o), Mahdalynivka (20.3\%o) and Petropavlivka (20.0\%) districts (Fig. 2).

The state of marital relations and the family structure of the population is also one of the factors that influence the birth rate of the population and the mobility of the working-age population, the ability to change the place of residence in search of new work, etc. The number of registered marriages has decreased by $3.8 \%$, which leads to an increase in the proportion of extramarital births.

Despite a slight decrease in mortality, nevertheless the number of deaths exceeds the birth rate by 1.5 times. The analysis of the causes of mortality shows an unjustifiably high number of deaths from accidents and those diseases that world medicine has been treating successfully. In 2017, for every 100 deaths, 67 were from circulatory diseases, 12 - from tumours, 6 - from external causes of death. Almost a quarter of all deceased (22.1\%) were persons of working age.

Analyzing the gender-age structure of the population, we note that it is dominated by women (by 290.4 thousand people in 2017). However, in the sex-age structure in all groups of up to 29 years, men prevail by $5.4 \%$, this ratio is a biological regularity, since there are always boys born more than girls.

For reproduction of the population, the ratio of men and women of reproductive age (women, usually 15-49 years, and men - from 15 to 55 years) is important, because of such a relationship characterises the reproduction of the population and the course of individual demographic processes. Starting from age groups 55 and over in the sexual structure, there is a significant imbalance between the number of women and men. As a result of higher mortality of men, in 2017 women in these age groups exceeded the number of men by 250.2 thousand people.

Analyzing the age structure of the population of Dnipropetrovsk region, we note that the share of the population aged below the working age has been the most affected, which in the future will negatively affect the formation of the labour resources of the region and lead to a reduction of the contingent of young people of working age. Such a situation of reproduction of labour resources requires the quantitative reduction to be compensated by ensuring the growth of the qualitative characteristics of the working-age population.
The total fertility rate (the average number of children borne to a woman during her entire period of childbearing) has slightly increased from 1.0 to 1.4 , but still it is insufficient, since at least 2.1 is required for stable replenishment of the population. A very high mortality rate is accompanied by an almost continuous increase in the number (and, accordingly, of the proportion) of people over the working age, that is, there is a process of «aging population». The share of persons of retirement age among the inhabitants of the agglomerations of the Dnipropetrovsk region is gradually increasing. In 2017 , it was $25.2 \%$, or a quarter of the total population.

In the age structure of the population almost $14.6 \%$ are children, $25.2 \%$ - the elderly and $60.7 \%$ - able-bodied population aged 15-70 years. The largest share of the population of working age is taken up by persons 25-29 years old, who make up $8.2 \%$, while the groups $20-24$ and 50-54 years old each make up $7.8 \%$ of the population. The smallest share of the population of working age is taken up by the age group of 65-69 years and is 3.8\%.

It should be noted that there is an increase in the number of people in the age groups from 25-29 years old (born in the period with high childbearing activity of the population - in the first half of the 80 's), as well as the age group of 50-54 years (who were a numerical cohort born in the late 1950s and the early 1960s. The largest proportion of the population above working aged is observed in Pavlohrad (29.5\%), in the Petropavlovka (29.3\%) and Petyikivka (29.0\%) districts, and the smallest in Novomoskovsk district (23.1\%). The largest share of the working-age population is characteristic for Dnipropetrovsk (60.2\%) and Novomoskovsk $(59.5 \%)$ districts; the lowest is for Sofievska district $(54.8 \%)$.

The average age of the population of the region is 40.7 years (male -37.8 years, female 43.2 years). It is estimated that the average life expectancy at birth in Dnipropetrovsk region was 69.16 years (63.82 for men, 74.37 years for women).

Thus, the natural reproduction of the population provides a continuous change of generations, creating quantitative boundaries of labour resources of urban agglomerations of Dnipropetrovsk region.

An important factor in the formation of the population and labour resources of Dnipropetrovsk region is its mechanical movement, that is, migration. Migrations of the population are the movement of people across the territory associated with the change of the permanent place of residence and work (Migration situation in Dnipropetrovsk 
region: state, problems and situation of solution, 2018).

Modern trends in migration in the agglomerations of Dnipropetrovsk region are characterized by the same processes as for the region as a whole. So, for a long time (mid-70's the end of 80-ies of the XX century) urban settlements of the Dnipropetrovsk region were characterized by a large mechanical increase in the population (Borisenko, O. 2016). This was due to the fact that the large scale of new construction, primarily in the coal and iron and steel industries, ferrous metallurgy and machine building, caused significant migration movements. A decrease of the same population in Dnipropetrovsk region occurred since 1993 as a result of both natural reduction and migration outflow. Starting from 2000 and up to 2010 , the number of people who arrived in the region for permanent residence was negligible, but still exceeded the number of people who left it. In this period, the intensity of migration declined sharply, due to the change in the population with a permanent place of residence. Since 2010 there has been a reverse trend, when the population began to rapidly decrease in the region, especially during the last two years, due to foreign migration, the intensive movement of refugees, and the transit through Ukraine of illegal migrants. This trend continues to this day, growth and gross migration (the amount of arrivals and departures) are decreasing each year (Table 1).

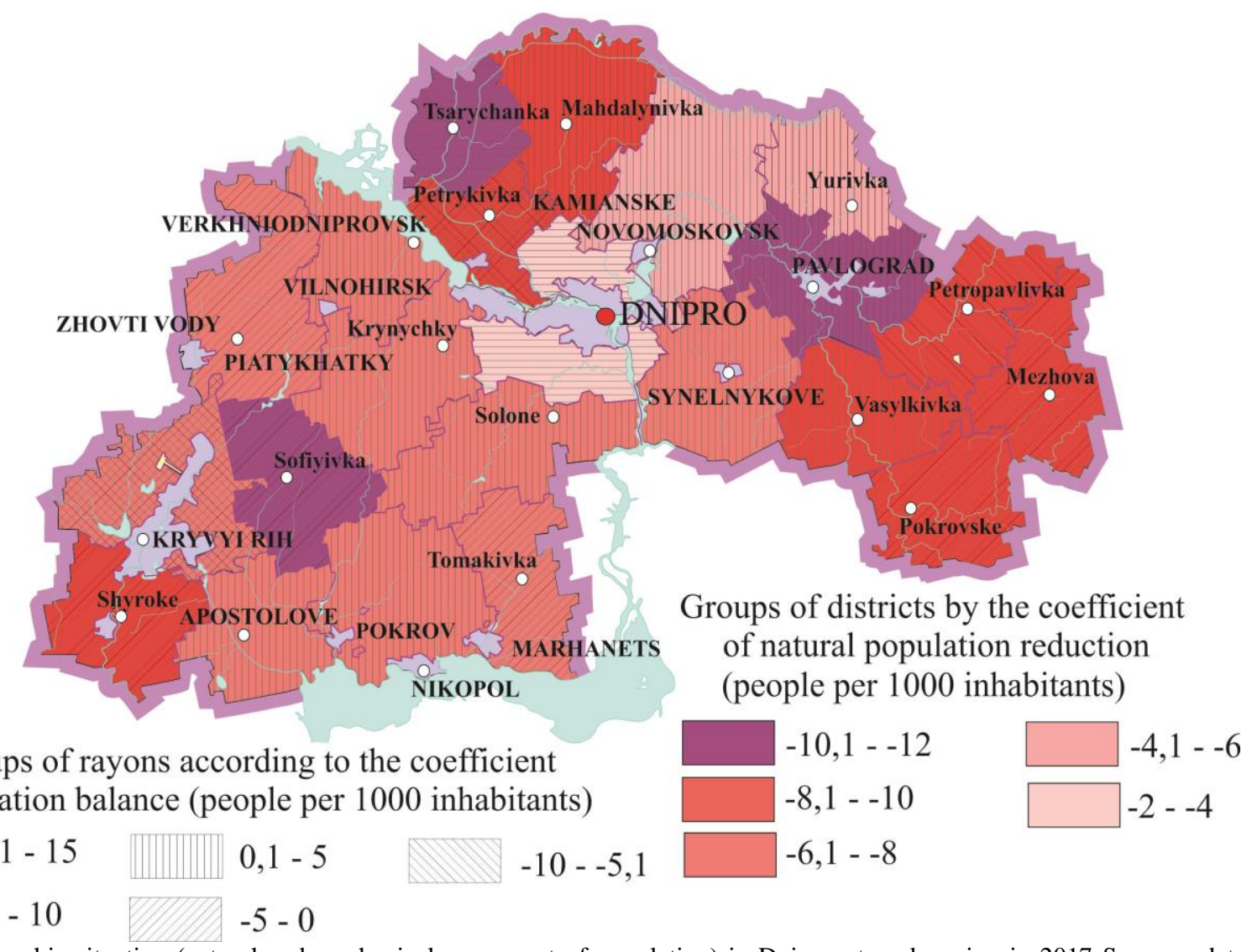

Fig. 2. Demographic situation (natural and mechanical movement of population) in Dnipropetrovsk region in 2017 Source: data retrieved from the official website Main Department of Statistics in Dnipropetrovsk Region

The modern mechanical gain has decreased by 1083 persons or by $0.1 \%$. And now Dnipropetrovsk region is one of the most migrantgiving and migrant-receiving regions of Ukraine (Main Department of Statistics in Dnipropetrovsk Region, 2018). This can be explained by the high industrial development of the region and the difficult political situation in the country as a whole. Complex migration processes take place against the background of industrial agglomerations of Dnipropetrovsk region, which reflect the general migration picture in the region as a whole.
In the Dnipro-Kamyanske agglomeration there is a complex demographic situation, as there has been a long decade of population decline, which indicates the inevitable processes of local depopulation (Table 2).

An important factor affecting the general migration processes in the largest agglomeration of Dnipropetrovsk region and, in particular, the growth of the population of the city of Dnipro in recent years is the unstable situation in the East of Ukraine. It has led to an increase in temporarily displaced people in need of employment, housing 
arrangements and social assistance. According to the Ministry of Social Policy of Ukraine (Ministry of Social Policy of Ukraine, 2018), in February 2018, in Dnipropetrovsk region, 73,600 temporarydisplaced persons were registered, the largest share settled in the city of Dnipro (estimated to 35-45 thousand). More than $70 \%$ of the settlers are retired (almost 33 thousand), disabled, disabled, having many children. This greatly complicates social pressure in the region, which increases the high unemployment rate in large cities.

Table 1. Dynamics of population migration in the Dnipropetrovsk region. Source: data retrieved from the official website Main Department of Statistics in Dnipropetrovsk Region

\begin{tabular}{|l|l|l|l|}
\hline Year & Number of arrivals, persons & $\begin{array}{l}\text { Number of departures, } \\
\text { persons }\end{array}$ & Migration growth (persons) \\
\hline 2010 & 46437 & 46465 & -28 \\
\hline 2011 & 46106 & 46321 & -215 \\
\hline 2013 & 45893 & 46253 & -360 \\
\hline 2014 & 39234 & 38803 & +431 \\
\hline 2015 & 37594 & 38945 & -1351 \\
\hline 2016 & 11437 & 13783 & -2346 \\
\hline 2017 & 51190 & 27059 & -24131 \\
\hline
\end{tabular}

Table 2. Dynamics of the population of cities of the Dnipro- Kamyanske agglomeration. Source:e data retrieved from the official website Main Department of Statistics in Dnipropetrovsk Region

\begin{tabular}{|l|l|l|l|l|l|}
\hline City & $\mathbf{2 0 1 0}$ & $\mathbf{2 0 1 2}$ & $\mathbf{2 0 1 4}$ & $\mathbf{2 0 1 6}$ & $\mathbf{2 0 1 7}$ \\
\hline Dnepr & 1007210 & 1000100 & 992200 & 978943 & 1002944 \\
\hline Kamyanske & 250115 & 248800 & 247600 & 244201 & 241990 \\
\hline Novomoskovsk & 70354 & 70800 & 71500 & 71111 & 70749 \\
\hline Sinelnikove & 31568 & 31600 & 31500 & 31114 & 30724 \\
\hline
\end{tabular}

Internal migration within the metropolitan area indicates a difficult situation in the city of Kamyanske (-264 people in 2016) and Nikopol (-47 people) and Solonyansky ( -3 persons) districts. In other cities and districts there is still a positive internal migration surplus (fewer leave than, than arrive). Especially in 2016, many people came from the region to the cities of Dnipro (875 people), Novomoskovsk (125), as well as Verkhnodniprovsk (735 people), Krynychky (552), Mahdalynivka (456) and Petyikivka (118) districts.

A very common type of displacement in the Dnipro-Kamyanske agglomeration is pendulum migration, which represents daily or weekly displacement of population from places of permanent residence to workplaces and in the opposite direction. A significant part of the urban (Kamyanske, Novomoskovsk, Pidgorodne) and the rural population of the nearby regions is engaged in labour in enterprises in Dnipro in the industrial sphere or service sector.

An important factor in the formation of the current demographic state of the agglomeration, in recent years, is the constant high external migration. It is due to the difficult economic situation in the country, which has developed in recent years, and especially has become massive after the abolition of the visa regime with the countries of the European Union in 2015. In 2008443 people from the cities of the metropolitan area went abroad, in $2016-2,194$ people, including from Dnipro - 1,786 people. As a rule, highly qualified specialists in the fields of medicine, science, education, high technologies, finance, etc left the cities for higher earnings abroad. In 2016 of rural areas of the agglomeration provided 406 foreign migrants, mostly of low qualification. With limited employment opportunities and low wages, many economically active citizens of this large agglomeration become labour migrants. Labour migration trips from Ukraine to the CIS countries, the European Union (mainly Poland, the Czech Republic, Slovakia, Hungary, Italy, Portugal, Greece) have become an objective reality and, without a doubt, a large-scale phenomenon of the present day.

Kryvyi Rih agglomeration is marked by a very difficult demographic situation, all its towns and most districts are steadily losing population both through natural and migration movements (Table 3 ).

Two types of migration - domestic and international - affect the overall migration balance of the Kryvyi Rih metropolitan area. Thus, in 2016, the balance of internal migration was traditionally negative in the cities of Kryviy Rih (-726 people) and Zhovti Vody (-92 persons), as well as in Apostolovo $(-31)$ and Sofievka (-39) districts. More came in Kryvyi Rih (+689 people) and Pyatyhatky (+307 people) districts and the number of people has not changed in Shiroke district during this period. In the internal movements, the number of men and women differs slightly. 
Table 3. The dynamics of the population of the towns of Kryvyi Rih agglomeration Source: data retrieved from the official website Main Department of Statistics in Dnipropetrovsk Region

\begin{tabular}{|c|c|c|c|c|c|}
\hline City & $\mathbf{2 0 1 0}$ & $\mathbf{2 0 1 2}$ & $\mathbf{2 0 1 4}$ & $\mathbf{2 0 1 6}$ & $\mathbf{2 0 1 7}$ \\
\hline Kryvyi Rih & 667874 & 659200 & 650500 & 639031 & 632422 \\
\hline Zhovti Vody & 48772 & 48300 & 47500 & 46374 & 45518 \\
\hline
\end{tabular}

Recently, international migration has intensified, due to which 1657 people left the cities and districts of the agglomerations in 2016. This has become an important social problem for Kryviy Rih, where demand for labour exceeds the supply. So, according to the Dnipropetrovsk Regional Employment Centre (Dnipropetrovsk Regional Employment Center, 2018), in Kriyvyi Rih, there was a shortage of workers. It is because of the mass labour migration from the cities of the agglomeration to the countries of the European Union that people of working age have begun en masse masses and most of them are representatives of working professions (turners, welders, milling machine operators, heavy truck drivers, miners). The largest flows of labour migrations from Kryvyi Rih were to Poland, the USA and Hungary. At the time of departure, more than half of the labour migrants worked in low-skilled jobs: almost $8 \%$ - skilled workers; $7 \%$ - workers engaged in maintenance, operation and control over the work of technological equipment, assembly of equipment and machines, almost 7\% - professionals and 5\% specialists. The most acute area of staff shortage in Kryvyi Rih is among representatives of mining specialties. Since employers cannot provide an adequate level of wages, sometimes whole brigades of workers leave their workplaces. Staff famine is also felt in metallurgical enterprises and in the service sector.

One of the leaders in reduction in population is Zhovty Vody. During the years of independence the city has lost almost $25 \%$ of its population. The reason for this is both depopulation and constantly increasing migration. Taking into account the very problematic ecological state of Zhovty Vody, the demographic situation is constantly deteriorating, the incidence, in particular, of malignant neoplasms is increasing. The level of malignant tumours in the city is higher than the indicators in general in Dnipropetrovsk region by $16 \%$, and the mortality rate from oncological diseases exceeds the average indicator for the region by almost $54 \%$. Therefore, the population is forced to look for new places of residence, including in Dnipro and other cities of Ukraine ; every year about 170-200 people from the city go abroad to live or work.

The complicated demographic situation in the towns of the Nikopol agglomeration has led to the stable long-term depopulation; the city of Nikopol is rapidly losing its population (Table 4).

Table 4. The dynamics of the population of the towns of the Nikopol agglomeration Source: data retrieved from the official website Main Department of Statistics in Dnipropetrovsk Region

\begin{tabular}{|c|c|c|c|c|c|}
\hline City & $\mathbf{2 0 1 0}$ & $\mathbf{2 0 1 2}$ & $\mathbf{2 0 1 4}$ & $\mathbf{2 0 1 6}$ & $\mathbf{2 0 1 7}$ \\
\hline Nikopol & 121784 & 118700 & 116800 & 113889 & 112102 \\
\hline Marhanets & 49697 & 49500 & 49200 & 48760 & 48139 \\
\hline Pokrov & 43617 & 43100 & 42600 & 41820 & 41195 \\
\hline
\end{tabular}

A noticeable decrease in the labour-resource potential of agglomeration cities is associated with both the reduction of the natural movement and the permanent departure of the population from these cities, both to other regions of Ukraine and abroad. In 2016 alone domestic migration reduced the local population by 502 people, especially large losses of population were observed in Nikopol (170 people) and Nikopol district (119 people). The population travels massively to large cities, including in the center of the oblast - to the city of Dnipro because of students studying there, and people looking for work in the service sector and at the enterprises of the city. The majority of those who left for other settlements of Ukraine are adults aged 17-25 who left to study or find a job. Among those who traveled to other settlements of Ukraine, more than 55\% were women.
Every year, external migration from agglomeration cities is intensifying. So, if in 2008 from cities of agglomeration 177 people moved abroad, then in 2016 the number was already 529 people, almost half of them being inhabitants of Nikopol (239 people). Mining and metallurgical enterprises of the agglomeration are experiencing a significant difficulty in filling vacancies. Thus, in 2018, one enterprise - the Ukrainian industrial company Interpipe, revealed shortages of personnel in pipe and wheel production at the level of 600 vacancies. Traveling to work in Poland, Slovakia or Hungary turned to be a real trend for the locals.

The forecast trends in demographic changes in this agglomeration indicate that as a result of population decline, there is a need to change the infrastructure of cities, as demand for different types of housing will change and the burden on public 
transport infrastructure will increase. Reduction in the population of working age due to mass migration will require an increase in labour productivity to ensure the economic growth of the agglomerations.
The Pavlohrad agglomeration is considered to be in the process of formation. However, it is also losing its population rapidly, and, as a consequence, labour resources (Table 5).

Table 5. Dynamics of the population of towns of Pavlohrad agglomeration Source: data retrieved from the official website Main Department of Statistics in Dnipropetrovsk Region

\begin{tabular}{|c|c|c|c|c|c|}
\hline City & $\mathbf{2 0 1 0}$ & $\mathbf{2 0 1 2}$ & $\mathbf{2 0 1 4}$ & $\mathbf{2 0 1 6}$ & $\mathbf{2 0 1 7}$ \\
\hline Pavlohrad & 110644 & 110100 & 109300 & 107742 & 106184 \\
\hline Ternivka & 28943 & 28900 & 29000 & 28719 & 28315 \\
\hline Pershotravensk & 29104 & 29000 & 28900 & 28696 & 28363 \\
\hline
\end{tabular}

Internal migration is marked by certain peculiarities. Among the three cities of the agglomeration only in Pavlohrad is there a negative balance of migration ( -58 persons), due to the fact that in 2016 only 150 people arrived in the city, and 208 left it. In the two other cities there is a reverse trend, they have a positive migration balance, In 2016, 120 people arrived there, and 90 people moved to Ukraine. Among those who go leave there are young people who go to large cities (including Dnipro) for study or in search of work. The administrative districts of the agglomeration also have a negative migration balance, and in general, they lost 83 people through the internal movements in 2016, in particular, Vasylkovka and Petropavlivka districts.

Foreign migration in agglomeration centers has a clear tendency to increase, especially since 2014. Thus, in 2016, 226 people left Pavlohrad (only 63 people arrived), and 103 people left Ternovka and Pershotravensk (51 persons arrived). The same negative the trend is peculiar also for rural areas, which in 2016 lost 126 people to departure abroad. As in previous agglomerations, local residents leave their homes in most cases for economic reasons - in search of work, better salary and life, and young people are trying to get higher education abroad and stay there.

So, the current state of migration processes in the agglomerations of Dnipropetrovsk region is caused by socio-economic and political problems. This has led to an increase in labour migration, which has now become already catastrophic. Negative consequences of this are the depopulation of cities and districts of the agglomerations, the outflow of the better quality labour force (and in particular qualified labour), the collapse of families, increase in crime and corruption, etc.

Conclusions. Thus, the demographic aspect due to natural and mechanical movements has become critical in shaping the labour-resource situation and affects not only the reproduction process itself, but also the structure of the economically active population of Dnipropetrovsk region .In the period1997 to 2017, in the urban agglomerations of Dnipropetrovsk region, the general demographic features of population reproduction were identified: a decrease in the total population, a negative natural population growth (mortality rates prevail over birth rates), aging of the population, which is expressed in an increase in the number of people aged 70 or over, disproportion in the sex structure of the population (prevalence of women), negative balance of migration and continuos outflow of inhabitants of reproductive age (mainly to EU countries).

\section{References}

Derzhavnij komitet statistiki Ukraïni, ofitsiinyi vebsait [State Committee of Statistics of Ukraine, official website]. Retrieved from http://www.ukrstat.gov.ua

Golovne upravlinnya statistiki u Dnipropetrovs'kij oblasti, ofitsiinyi vebsait [Main Department of Statistics in Dnipropetrovsk Region, official website]. Retrieved from http://www.dneprstat.ua.

Migracijna situaciya u Dnipropetrovs'kij oblasti: stan, problemi i shlyahi ïh virishennya [Migration situation in Dnipropetrovsk region: state, problems and situation of solution]. Retrieved from

http://migraciya.com.uanews/GeneralDirectorateo fLCAinDnipropetrovskregion/ua-migrationsituation-in-dni- propetrovsk-oblast---state-proble ms-and-solutions/

Borisenko, O. 2016. Social'no-ekonomichni problemi migracijnih procesiv (na prikladi Dnipropetrovs'koï oblasti) [Socio-economic problems of migration processes (for example, Dnipropetrovsk region)]. Retrieved from http://nbuv.gov.ua/ UJRN/ecpros_2016_111_10

Golovne upravlinnya derzhavnoï migracijnoï sluzhbi u Dnipropetrovs'kij oblasti oblasti, ofitsiinyi vebsait [Main Directorate of the State Migration Service in Dnipropetrovsk region, official website]. Retrieved from http://www.dp.dmsu.gov.ua.

Ministerstvo social'noï politiki Ukraïni, ofitsiinyi vebsait [Ministry of Social Policy of Ukraine, official website]. Retrieved from https://www.msp.gov.ua.

Dnipropetrovs'kij oblasnij centr zajnyatosti, ofitsiinyi vebsait [Dnipropetrovsk Oblast Employment Center, official website]. Retrieved from https://www.dcz.gov.ua/dnp/ 